\title{
ANALISIS POTENSI EKONOMI KABUPATEN BANYUWANGI
}

\author{
Oleh: \\ Ahmad Afan Ayubi \\ Bank Mandiri Syariah Balikpapan Kalimantan Timur \\ E-mail: alayubirabbani@yahoo.co.id
}

\begin{abstract}
The purpose of this study was to identify sectors of potential economic, competitive competitive, comparative and specialization, to then be used as a driver of economic growth and development of the district of Banyuwangi. This type of research is descriptive quantitative research. The data used in this research is secondary data and time series. These results indicate that by Location Quotient (LQ), the sector identified as a leading sector is agriculture. Based on the average results of analysis Growth Ratio Method (MRP), shows found their economic sectors that stand at both district and provincial Banyuwangi East Java, with the construction sector and the sectors of trade, hotel and restaurant.
\end{abstract}

Keywords: regional economic potential, Location Quotient (LQ), Method of Growth Ratio, Overlay analysis, analysis Shift-share.

\begin{abstract}
Abstrak
Tujuan penelitian ini adalah untuk mengidentifikasi sektor-sektor ekonomi yang potensial, berdaya saing kompetitif, komparatif maupun spesialisasi, untuk kemudian digunakan sebagai pendorong pertumbuhan ekonomi dan pengembangan wilayah Kabupaten Banyuwangi. Jenis penelitian ini adalah penelitian diskriptif kuantitatif. Data yang digunakan dalam penelitian ini adalah data skunder dan time series. Hasil penelitian ini menunjukan bahwa berdasarkan analisis Location Quotient $(L Q)$, sektor yang teridentifikasi sebagai sektor unggulan adalah sektor pertanian. Berdasarkan rata-rata hasil analisis Metode Rasio Pertumbuhan (MRP), menunjukan ditemukan adanya sektor ekonomi yang menonjol baik ditingkat Kabupaten Banyuwangi maupun propinsi Jawa Timur yaitu sektor bangunan dengan dan sektor perdaganan, hotel and restaurant.
\end{abstract}

Kata Kunci: Potensi Ekonomi Daerah, Location Quotient (LQ), Metode Rasio Pertumbuhan (MRP), analisis Overlay, analisis Shift-share.

\section{PENDAHULUAN}

\author{
Keberhasilan pembangunan \\ nasional sangat bergantung pada
}

keberhasilahan pembangunan daerah.

Daerah dituntut untuk selalu meningkatkan kemampuannya dalam pengelolaan potensi daerahnya. (John 


\section{Analisis Potensi Ekonomi Kabupaten Banyuwangi (Ahmad Afan Ayubi)}

Glasson, 1990 dalam Nudiatulhuda, 2007) mengatakan bahwa kemakmuran suatu wilayah berbeda dengan wilayah lainnya. Perbedaan tersebut disebabkan oleh perbedaan pada struktur ekonominya dan faktor ini merupakan faktor utama. Perubahan wilayah kepada kondisi yang lebih makmur tergantung pada usaha-usaha di daerah tersebut dalam menghasilkan barang dan jasa, serta usaha-usaha pembangunan yang diperlukan. Oleh sebab itu maka kegiatan basis mempunyai peranan penggerak utama (prime mover role) dalam pertumbuhan ekonomi suatu daerah, dimana setiap perubahan mempunyai efek multiplier terhadap perekonomian regional. Berdasarkan teori basis ekonomi, faktor penentu utama pertumbuhan ekonomi suatu daerah adalah berhubungan langsung dengan permintaan akan barang dan jasa dari luar daerah (Arsyad,1999).

Kabupaten Banyuwangi sebagai salah satu kabupaten yang berada di Provinsi Jawa Timur merupakan daerah otonom yang memiliki andil dalam mewujudkan pembangunan nasional melalui pencapaian pembangunan daerah. Keberhasilan akan pembangunan nasional yang juga didukung dari keberhasilan pembangunan daerah menjadi sangat penting bagi setiap pemerintah daerah termasuk Kabupaten Banyuwangi untuk selalu mendorong laju pembanguanan baik pembangunan fisik maupun pembangunan non fisik seperti pembangunan ekonomi dengan meningkatkatkan pertumbuhan ekonomi yang kemudian akan menjadikan masyarakat semakin sejahtera.

Letak geografis Banyuwangi sangat strategis, berada di ujung timur pulau Jawa merupakan pintu gerbang koridor ekonomi Jawa sebagai "Pendorong Industri dan Jasa Nasional", yang menghubungkan dengan koridor ekonomi Bali Nusa Tenggara sebagai "Pintu Gerbang Pariwisata dan Pendukung Pangan Nasional". Selain itu sumber daya alam yang cukup melimpah tersedia di wilayah Kabupaten Banyuwangi. Menurut data statistik, potensi lahan pertanian di Kabupaten Banyuwangi berada dalam peringkat ketiga setelah kabupaten Malang dan Jember. Sehingga tidak mengherankan apabila Kabupaten Banyuwangi menjadi 
Analisis Potensi Ekonomi Kabupaten Banyuwangi (Ahmad Afan Ayubi)

bagian dari salah satu lumbung Banyuwangi, namun menjadi pangan di provinsi Jawa Timur. lokomotif utama yang mengangkat Selain potensi dibidang pertanian, tumbuhnya perekonomian. Sektor ini Kabupaten Banyuwangi memiliki pada tahun 2011 mampu tumbuh 8,9 bentangan pantai yang cukup persen dan pada tahun 2012 mencapai panjang, sehingga ke depan, posisi 9,2 persen melampaui total pengembangan sumberdaya kelautan pertumbuhan ekonomi Banyuwangi. dapat menjadi fokus perhatian Sedangkan sektor pertanian yang pemerintah dalam meningkatkan menjadi unggulan utama, hanya sektor tersebut melalui berbagai tumbuh rata-rata 5 persen. Ketika upaya intensifikasi dan diversifikasi penge-lolaan kawasan pantai dan wilayah perairan laut. Bukan hal yang tidak mungkin apabila percepatan pengem-bangan sektor - sektor potensial seperti kekayaan laut dan sektor potensial lainnya ini dapat segera terwujud mengingat potensi yang dimiliki cukup besar.

Menurut laporan Banyuwangi Economic Outlook 2012 (Sectoral Analysis), sektor pertanian menjadi sektor andalan Banyuwangi, sumbangsihnya paling tinggi diantara sembilan sektor lainnya terhadap PDRB menjadikan sektor pertanian sebagai sektor unggulan dibebearapa tahun terakhir. Sementara itu, sektor perdagangan, hotel dan restoran, meskipun dalam posisi kedua dalam memberi kontribusi ekonomi sektor perdagangan, jasa, dan restoran serta sektor konstruksi mengalami trend peningkatan, sektor lainnya akan mengalami trend penurunan. Kondisi ini menunjukkan bahwa saat ini Banyuwangi dalam proses transformasi, dari pertanian ke sektor jasa perdagangan. Sektor pertanian, di samping pertumbuhannya lambat, kontribusinya terhadap total PDRB semakin tahun semakin menurun.

Tahun 2007 - 2008 kontribusi sektor pertanian pada posisi diatas 47 persen, namun pada tahun 2010 turun menjadi 46 persen dan turun lagi pada posisi 45,9 persen pada tahun 2011. Sedangkan pada sektor perdagangan, hotel dan restoran, yang menjadi lokomotif pertumbuhan ekonomi Banyuwangi, faktanya merupakan sektor 'terbelakang' dalam konstelasi 
Analisis Potensi Ekonomi Kabupaten Banyuwangi (Ahmad Afan Ayubi)

ekonomi Jawa Timur. Rata - rata pertumbuhan sektor perdagangan, hotel dan restoran Jawa Timur lebih tinggi daripada Banyuwangi. Inilah tantangan yang masih harus dihadapi saat ini dan pada tahun-tahun mendatang.

Meskipun ekonomi Banyuwangi meunjukan pergerakan yang stabil dan tumbuh meningkat, namun beban dan tantangan masih terbilang cukup tinggi. Perubahan pola sektoral ekonomi yang terjadi seperti telah dijelaskan diatas harus segera mendapat penanganan yang cepat dan tepat sehingga tidak terjadi kebijakan yang salah sasaran, apalagi mengingat saat ini di kawawasan Banyuwangi selatan telah ditemukan sumberdaya alam baru berupa tambang emas, yang kemungkinan bisa menjadi sektor unggulan baru. Penentuan sektor basis sangat perlu segera dilaksankan untuk menentukan sektor mana yang akan mendorong peningkatan PDRB Banyuwangi dan akan menajdi penopang perekonomian. Identifikasi sektor basis yang akan diprioritaskan menjadi sangat penting untuk segera dikerjakan agar daerah dapat segera menggunakan potensi ekonominya secara maksimal.

Dari pemaparan bahasan diatas maka diperlukan adanya suatu penelitian untuk mengetahui potensi ekonomi serta identifikasi sektorsektor yang potensial dan sektor prioritas di Kabupaten Banyuwangi sebagai pedoman dalam merumuskan perencanaan dan pelaksanaan pembangunan untuk meningkatkan pertumbuhan ekonomi serta diera otonomi daerah saat ini.

\section{METODOLOGI PENELITIAN}

Alat analisis yang digunakan dalam penelitian ini adalah Location Quotient yang bertujuan untuk membandingkan besarnya peranan suatu sektor disuatu daerah terhadap peranan suatu sektor tersebut secara nasional atau di suatu kabupaten terhadap peranan suatu sektor secara regional atau tingkat provinsi. Analisis Model Rasio Pertumbuhan merupakan alat analisis yang digunakan untuk melihat deskripsi kegiatan ekonomi (sektor ekonomi) yang potensial, terutama struktur ekonomi kabupaten atau kota maupun 
Analisis Potensi Ekonomi Kabupaten Banyuwangi (Ahmad Afan Ayubi)

provinsi Jawa Timur berdasarkan pada kriteria pertumbuhan struktur ekonomi wilayah baik internal maupun eksternal (Yusuf, 1999, dalam Putra, 2013). Analisis Shiftt Share merupakan tehnik yang menggambarkan performance (kinerja) sektor - sektor di suatu wilayah dibandingkan kinerja sektor sektor perekonomian nasional. Dengan demikian dapat ditemukan adanya Shiftt (pergeseran) hasil pembangunan perekonomian daerah, bila daerah itu memperoleh kemajuan lebih lambat atau lebih cepat dari kemajuan nasional.
Untuk mengetahui sektor potensial di suatu daerah, alat analisis yang digunakan adalah dengan melihat nilai Location Quotients (LQ), yang merupakan perbandingan kontribusi masing-masing sektor terhadap pembentukan PDRB Kabupaten Banyuwangi dengan PDRB Provinsi Jawa Timur. Jika nilai LQ > 1 maka sektor tersebut dapat dikatakan sebagai sektor potensial (basis). Apabila nilai LQ $<1$ maka sektor tersebut bukan merupakan sektor potensial (non basis). Berikut dapat dilihat hasil perhitungan LQ secara lengkap pada (tabel 1)

\section{HASIL PENELITIAN DAN \\ PEMBAHASAN}

Tabel 1 : Hasil Analisis Location Quotients Kabupaten Banyuwangi Tahun 2008-2012

\begin{tabular}{llrrrrrc}
\hline & \multicolumn{6}{c}{ Tahun } \\
\cline { 2 - 7 } No Lapangan Usaha & $\mathbf{2 0 0 8}$ & $\mathbf{2 0 0 9}$ & $\mathbf{2 0 1 0}$ & $\mathbf{2 0 1 1}$ & $\begin{array}{c}\mathbf{2 0 1} \\
\mathbf{2}\end{array}$ & $\begin{array}{c}\text { Rata- } \\
\text { rata }\end{array}$ \\
\hline 1 & Pertanian & 3.01 & 3.03 & 3.14 & 3.23 & 3.29 & 3.14 \\
\hline 2 & $\begin{array}{l}\text { Pertambangan dan } \\
\text { Penggalian }\end{array}$ & 2.00 & 1.97 & 1.94 & 1.97 & 2.05 & 1.99 \\
\hline 3 & Industri Pengolahan & 0.24 & 0.25 & 0.25 & 0.25 & 0.25 & 0.25 \\
\hline 4 & Listrik, Gas, \& Air Bersih & 0.34 & 0.35 & 0.34 & 0.33 & 0.33 & 0.34 \\
\hline 5 & Bangunan & 0.26 & 0.26 & 0.26 & 0.27 & 0.28 & 0.27 \\
\hline 6 & $\begin{array}{l}\text { Perdagangan, Hotel \& } \\
\text { Restauran }\end{array}$ & 0.82 & 0.82 & 0.81 & 0.82 & 0.83 & 0.82 \\
\hline
\end{tabular}


Analisis Potensi Ekonomi Kabupaten Banyuwangi (Ahmad Afan Ayubi)

\begin{tabular}{|c|c|c|c|c|c|c|c|}
\hline 7 & $\begin{array}{l}\text { Pengangkutan \& } \\
\text { Komunikasi }\end{array}$ & 0.68 & 0.63 & 0.60 & 0.58 & 0.56 & 0.61 \\
\hline 8 & $\begin{array}{l}\text { Keuangan, Persewaaan \& } \\
\text { Jasa Perusahaan }\end{array}$ & 1.13 & 1.11 & 1.08 & 1.07 & 1.06 & 1.09 \\
\hline 9 & Jasa-jasa & 0.60 & 0.59 & 0.60 & 0.61 & 0.62 & 0.60 \\
\hline
\end{tabular}

Sumber : Data diolah

Hasil perhitungan rata-rata LQ

tumbuhan sektor yang sama dalam tahun 2008 - 2012 menunjukan perekonomian di Jawa Timur.

bahwa sektor ekonomi di Kabupaten

Analisis model rasio per-

Banyuwangi yang tergolong dalam tumbuhan (MRP) merupakan salah kategori sektor basis dengan kriteria hasil nilai perhitungan LQ lebih besar dari 1 yaitu ada tiga (3) sektor, yaitu sektor pertanian dengan nilai LQ (3.14), sektor pertambangan dan penggalian dengan nilai LQ (1.99), dan sektor keuangan, persewaan \& jasa perusahaan dengan nilai LQ (1.09). Ini berarti bahwa laju pertumbuhan ketiga sektor di Kabupaten Banyuwangi lebih besar dibandingkan dengan laju persatu alat analisis alternatif guna mendukung penentuan deskripsi kegiatan ekonomi yang potensial di kabupaten Banyuwangi. MRP ini serupa dengan LQ, perbedaanya terletak pada cara menghitung. Analisis LQ menggunakan distribusi PDRB, sedangkan MRP menggunakan kriteria pertumbuhan. Analisis LQ menggunakan distribusi PDRB, sedangkan MRP menggunakan kriteria pertumbuhan.

Tabel 2

Rata-rata hasil Analisis Model Rasio Pertumbuah (MRP) Kabupaten Banyuwangi Tahun 2008-2012

\begin{tabular}{|c|l|c|c|c|c|}
\hline \multirow{2}{*}{ No } & \multicolumn{2}{|c|}{ Lapangan Usaha } & \multicolumn{2}{c|}{ RPr } & \multicolumn{2}{c|}{ RPs } \\
\cline { 3 - 6 } & & N & R & N & R \\
\hline 1. & Pertanian & 0.49 & - & 1.88 & + \\
\hline 2. & Pertambangan dan Penggalian & 0.97 & - & 1.50 & + \\
\hline 3. & Industri Pengolahan & 0.73 & - & 1.21 & + \\
\hline 4. & Listrik, Gas, \& Air Bersih & 0.81 & - & 1.12 & + \\
\hline 5. & Bangunan & 1.02 & + & 1.20 & + \\
\hline 6. & Perdagangan, Hotel \& Restauran & 1.36 & + & 1.09 & + \\
\hline 7. & Pengangkutan \& Komunikasi & 1.75 & + & 0.55 & - \\
\hline
\end{tabular}


Analisis Potensi Ekonomi Kabupaten Banyuwangi (Ahmad Afan Ayubi)

\begin{tabular}{|c|l|c|c|c|c|}
\hline 8. & $\begin{array}{l}\text { Keuangan, Persewaaan \& Jasa } \\
\text { Perusahaan }\end{array}$ & 1.10 & & 0.76 & + \\
\hline 9. & Jasa-jasa & 0.80 & - & 1.52 & + \\
\hline
\end{tabular}

Sumber : Lampiran IV dan lampiran $V$

Keterangan : $\mathrm{N}=$ Nilai $\mathrm{R}=$ Rangking

Berdasarkan tabel 2 diatas,

pertumbuhan sektor yang sama

dapat diketahui bahwa rata-rata hasil

pada wilayah Jawa Timur, serta pengujian MRP di Kabupaten Banyuwangi selama kurun waktu 2008 - 2012 menempatkan sektorsektor ekonomi ke dalam kategori berikut ini:

a. Klasifikasi pertama, jika nilainya (+) dan (+) maka sektor tersebut memiliki pertumbuhan yang menonjol baik di tingkat Kabupaten Banyuwangi maupun di Propinsi Jawa Timur, dimana kegiatan ini disebut dominan pertumbuhan. Sektor yang masuk dalam klasifikasi ini adalah sektor bangunan dengan nilai $\mathrm{RPr}(1.02)$ dan nilai RPs (1.20), dan sektor perdagangan hotel \& restaurant dengan nilai $\operatorname{RPr}(1.36)$ dan nilai RPs (1.09). Hal ini artinya bahwa nilai RPs > 1 menunjukan pertumbuhan sektor bangunan maupun sektor perdagangan, hotel $\&$ restauran pada tingkat wilayah Kabupaten Banyuwangi lebih tinggi dibandingkan dengan nilai $\operatorname{RPr}>1$ menunjukan pertumbuhan sektor bangunan maupun sektor perdagangan, hotel \& restauran dalam wilayah Jawa Timur lebih tinggi dari pertumbuhan PDRB total wilayah yang sama.

b. Klasifikasi kedua, jika nilainnya (+) dan (-) maka sektor tersebut memiliki pertumbuhan menonjol di Propinsi Jawa Timur, akan tetapi kurang menonjol di Kabupaten Banyuwangi. Kegiatan ekonomi yang potensial di Kabupaten Banyuwangi yaitu sektor yang masuk dalam klasifikasi ini adalah sektor pengangkutan \& komunikasi dengan nilai RPr (1.75) dan RPs (0.55), serta sektor keuangan, persewaaan \& jasa perusahaan dengan nilai RPr (1.10) dan RPs (0.75). Hal ini artinya bahwa nilai RPs $<1$ menunjukan pertumbuhan sektor sektor pengangkutan \& 
Analisis Potensi Ekonomi Kabupaten Banyuwangi (Ahmad Afan Ayubi)

komunikasi maupun sektor keuangan, persewaaan \& jasa perusahaan pada tingkat wilayah Kabupaten Banyuwangi lebih rendah dibandingkan dengan pertumbuhan sektor yang sama pada wilayah Jawa Timur, serta nilai $\mathrm{RPr}>1$ menunjukan pertumbuhan sektor bangunan maupun sektor perdagangan, hotel \& restauran dalam wilayah Jawa Timur lebih tinggi dari pertumbuhan PDRB total wilayah yang sama.

c. Klasifikasi ketiga, jika nilainnya (-) dan (+) maka sektor tersebut memiliki pertumbuhan menonjol di Kabupaten Banyuwangi, namun kurang menonjol di tingkat propinsi Jawa Timur. Kegiatan ekonomi yang potensial di Kabupaten Banyuwangi yaitu sektor yang masuk dalam klasifikasi ini adalah sektor pertanian dengan nilai $\operatorname{RPr}(0.49)$ dan RPs (1.88), sektor pertambangan dan penggalian nilai RPr (0.97) dan RPs (1.50), sektor industri pengolahan nilai RPr (0.73) dan RPs (1.21), sektor listrik, gas, \& air bersih nilai RPr
(0.81) dan RPs (1.12), serta sektor jasa-jasa dengan nilai $\operatorname{RPr}(0.80)$ dan RPs (1.52). Hal ini artinya bahwa nilai RPs > 1 menunjukan pertumbuhan sektor pertanian, sektor pertambangan dan penggalian. sektor industri pengolahan, sektor listrik, gas, \& air bersih, sektor jasa-jasa pada tingkat wilayah Kabupaten Banyuwangi lebih tinggi dibandingkan dengan pertumbuhan sektor yang sama pada wilayah Jawa Timur, serta nilai $\mathrm{RPr}<1$ menunjukan pertumbuhan sektor pertanian, sektor pertambangan dan penggalian. sektor industri pengolahan, sektor listrik, gas, \& air bersih, sektor jasa-jasa dalam wilayah Jawa Timur lebih rendah dari pertumbuhan PDRB total wilayah yang sama.

d. Klasifikasi keempat, jika nilainnya (-) dan (-) maka sektor tersebut memiliki pertumbuhan yang kurang menonjol baik di Propinsi Jawa Timur maupun Kabupaten Banyuwangi. Sektor yang masuk dalam klasifikasi ini tidak ada. 
Analisis Potensi Ekonomi Kabupaten Banyuwangi (Ahmad Afan Ayubi)

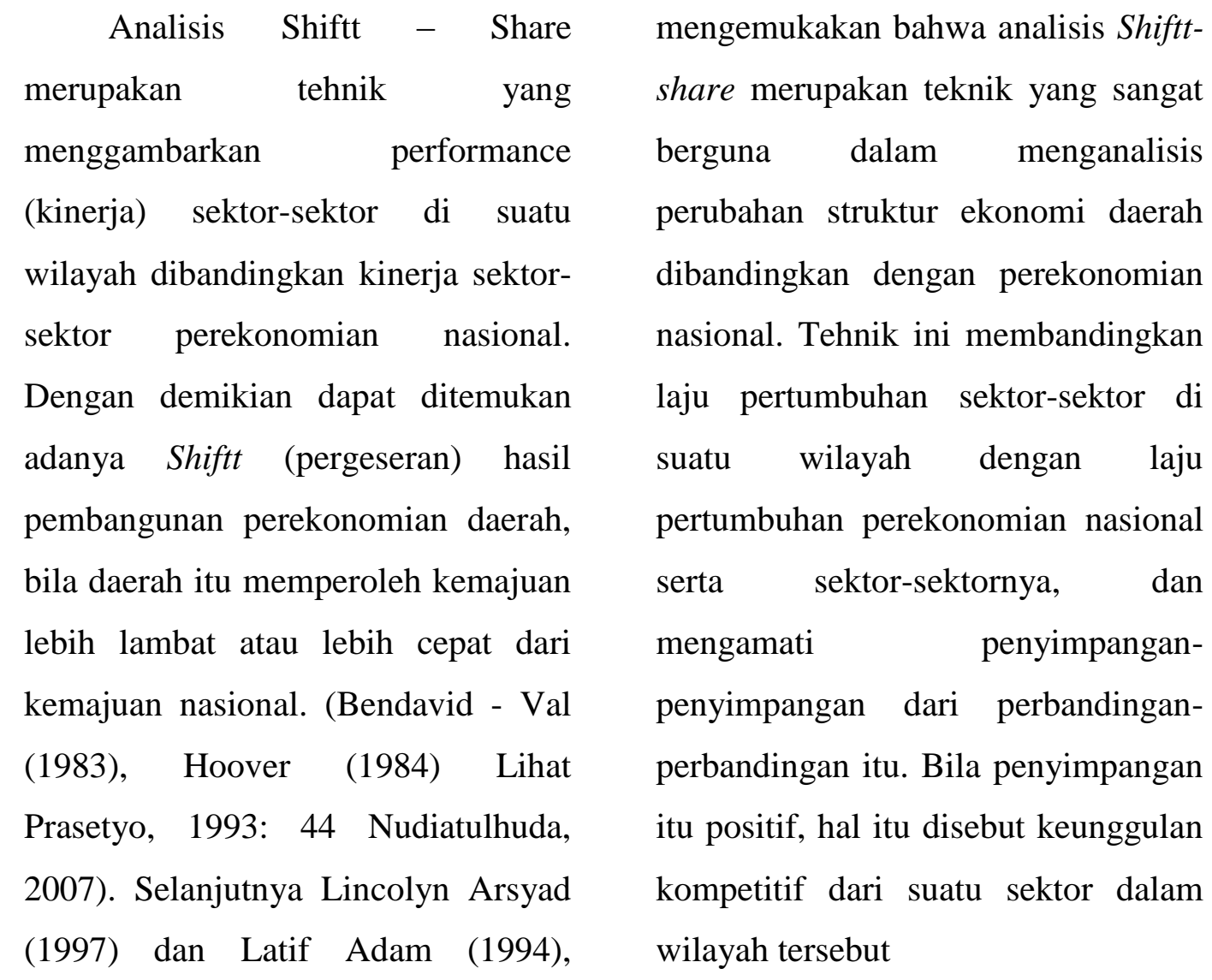

Tabel 3 : Rata-rata hasil Analisis Shift-Share Kabupaten Banyuwangi Tahun 2008-2012

\begin{tabular}{clccccc}
\hline \multirow{2}{*}{ No } & Lapangan Usaha & \multicolumn{7}{c}{ Shift -Share } \\
\cline { 2 - 7 } & N & K & N & S & Keterangan \\
\hline 1 & Pertanian & 3424523.66 & + & 0.02428 & + & ++ \\
\hline 2 & $\begin{array}{l}\text { Pertambangan dan } \\
\text { Penggalian }\end{array}$ & 232014.97 & + & 0.00717 & + & ++ \\
\hline 3 & Industri Pengolahan & -2078192.91 & - & 0.00614 & + & -+ \\
\hline 4 & $\begin{array}{l}\text { Listrik, Gas, \& Air } \\
\text { Bersih }\end{array}$ & -96710.79 & - & -0.00501 & - & -- \\
\hline 5 & Bangunan & -255106.06 & - & 0.01540 & + & -+ \\
\hline 6 & $\begin{array}{l}\text { Perdagangan, Hotel } \\
\text { \& Restauran }\end{array}$ & -598088.01 & - & 0.00491 & + & -+ \\
\hline 7 & $\begin{array}{l}\text { Pengangkutan \& } \\
\text { Komunikasi }\end{array}$ & -294970.52 & - & -0.05065 & - & -- \\
\hline 8 & $\begin{array}{l}\text { Keuangan, } \\
\text { Persewaaan \& Jasa } \\
\text { Perusahaan }\end{array}$ & 54832.95 & + & -0.01687 & - & +- \\
\hline 9 & Jasa-jasa & -388285.78 & - & 0.00922 & + & -+ \\
\hline Sumber: Data Diolah & & & & &
\end{tabular}


Analisis Potensi Ekonomi Kabupaten Banyuwangi (Ahmad Afan Ayubi)

Keterangan $: \mathrm{N}=$ nilai perhitungan $\mathrm{K}=$ Kompetitif

Berdasarkan rata-rata hasil analisis Shift - Share (S-S) tahun analisis 2008-2012, dapat diketahui sektor-sektor yang mempunyai keunggulan kompetitif dan spesialisasi di Kabupaten Banyuwangi adalah:

a. Jika spesialisasi sektor bernilai positif (+) dan keunggulan kompetitif bernilai negatif (-) maka sektor tersebut masuk dalam kriteria specialized, competitive disadvantage. Artinya apabila jumlah PDRB sektor i di Kabupaten Banyuwangi $\left(\mathrm{E}_{\mathrm{ij}}\right)$ lebih besar dari jumlah PDRB sektor i yang diharapkan di Kabupaten Banyuwangi $\quad\left(\mathrm{E}_{\mathrm{ij}}\right), \quad$ tetapi pertumbuhan sektor i di kabupaten Banyuwangi lebih rendah dari pada laju pertumbuhan sektor i di provinsi Jawa Timur. Sektor yang masuk dalam kategori ini adalah sektor industri pengolahan, sektor bangunan, sektor perdagangan, hotel \& restaurant dan sektor jasajasa.
$\mathrm{S}=$ Spesialisasi

b. Jika spesialisasi sektor bernilai negatif (-) dan keunggulan kompetitif bernilai negatif (-) maka sektor tersebut masuk dalam kriteria not specialized, competitive disadvantage. Artinya apabila jumlah PDRB sektor i di Kabupaten Banyuwangi $\left(\mathrm{E}_{\mathrm{ij}}\right)$ lebih rendah dari jumlah PDRB sektor i yang diharapkan di Kabupaten Banyuwangi ( $\left.E^{\prime}{ }^{\prime}\right), \quad$ serta pertumbuhan sektor i di kabupaten Banyuwangi lebih rendah dari pada laju pertumbuhan sektor i di provinsi Jawa Timur. Sektor yang masuk dalam kategori ini adalah sektor pengangkutan \& komunikasi, dan sektor listrik, gas, \& air bersih.

c. Jika spesialisasi sektor bernilai negatif (-) dan keunggulan kompetitif bernilai positif (+) maka sektor tersebut masuk dalam kriteria not specialized, competitive advantage. Artinya apabila jumlah PDRB sektor i di Kabupaten Banyuwangi $\left(\mathrm{E}_{\mathrm{ij}}\right)$ lebih rendah dari jumlah PDRB sektor i yang diharapkan di Kabupaten 
Analisis Potensi Ekonomi Kabupaten Banyuwangi (Ahmad Afan Ayubi)

Banyuwangi $\left(\mathrm{E}^{\prime}{ }_{\mathrm{ij}}\right)$, tetapi kabupaten Banyuwangi lebih pertumbuhan sektor i di besar dari pada laju pertumbuhan kabupaten Banyuwangi lebih besar dari pada laju pertumbuhan sektor i di provinsi Jawa Timur. Sektor ekonomi yang masuk dalam kategori ini adalah sektor keuangan, persewaaan \& jasa perusahaan.

d. Jika spesialisasi sektor bernilai positif (+) dan keunggulan kompetitif bernilai positif (+) maka sektor tersebut masuk dalam kriteria specialized, competitive advantage. Artinya apabila jumlah PDRB sektor i di Kabupaten Banyuwangi $\left(\mathrm{E}_{\mathrm{ij}}\right)$ lebih besar dari jumlah PDRB sektor i yang diharapkan di Kabupaten Banyuwangi $\quad\left(E_{i j}\right), \quad$ serta pertumbuhan sektor i di

\section{Tabel 4.}

Sektor Prioritas di Kabupaten Banyuwangi

Sektor ekonomi yang masuk dalam kategori ini adalah sektor pertanian dan sektor pertambangan dan penggalian.

Dari hasil analisis LQ, $\mathrm{S}-\mathrm{S}$ untuk keunggulan kompetitif dan spesialisasi serta Model Rasio Pertumbuhan yang semuanya diskorkan sesuai dengan range yang ada sesuai dengan nilai absolut yang ada di masing - masing sektor dalam kategori. Dari hasil perhitungan analisis dari setiap alat analisis yang digunakan dalam penelitian akan diambil sektor-sektor ekonomi yang memiliki nilai tertinggi untuk dijadikan sebagai sektor prioritas di Kabupaten Banyuwangi. 
Berdasarkan hasil perhitungan analisis LQ, analisis RPs, analisis Shift-Share keunggulan kompetitif dan kunggulan spesialisasi, kemudian telah dibuat skala prioritas menunjukan hasil sektor ekonomi yang termasuk dalam sektor prioritas pertama (ke-1) adalah sektor pertanian dan sektor pertambangan dan penggalian. Sektor ekonomi yang masuk prioritas kedua (ke-2) adalah sektor industri pengolahan, sektor bangunan, sektor perdagangan, hotel \& restauran, sektor Keuangan, persewaaan \& jasa perusahaan dan sektor jasa-jasa. Sedangkan sektor ekonomi yang masuk dalam prioritas ketiga (ke-3) adalah sektor listrik, gas, \& air bersih.

$$
\begin{array}{cc}
\multicolumn{2}{c}{\text { Teridentifikasinya }} \\
\text { sektor ekonomi di wilayah }
\end{array}
$$
Kabupaten Banyuwangi, maka sektor-sektor yang masuk dalam kategori prioritas pertama ke-1 yaitu sektor pertanian dan sektor pertambangan \& penggalian dapat digunakan untuk mendorong pengembangan dan pembangunan

\begin{tabular}{|c|c|c|c|c|c|c|c|c|c|c|c|}
\hline \multirow{2}{*}{ No } & \multirow{2}{*}{$\begin{array}{c}\text { Lapangan } \\
\text { Usaha }\end{array}$} & \multicolumn{2}{|c|}{ Analisis LQ } & \multicolumn{2}{|c|}{ RPs } & \multicolumn{2}{|c|}{$\begin{array}{c}\text { Keungggulan } \\
\text { Kompetitif }\end{array}$} & \multicolumn{2}{|c|}{$\begin{array}{l}\text { Keunggulan } \\
\text { Spesialisasi }\end{array}$} & \multirow{2}{*}{$\begin{array}{l}\text { Total } \\
\text { Skor } \\
\text { jumlah }\end{array}$} & \multirow[t]{2}{*}{$\begin{array}{l}\text { Sektor } \\
\text { Priorit } \\
\text { as } \\
\end{array}$} \\
\hline & & Nilai & Skor & Nilai & Skor & Nilai & Skor & Nilai & Skor & & \\
\hline 1 & Pertanian & 3.14 & 1 & 1.88 & 1 & $\begin{array}{c}342452 \\
3.66 \\
\end{array}$ & 1 & $\begin{array}{c}0.02 \\
428 \\
\end{array}$ & 1 & 4 & 1 \\
\hline 2 & $\begin{array}{l}\text { Pertambangan } \\
\text { dan } \\
\text { Penggalian }\end{array}$ & 1.99 & 1 & 1.50 & 1 & $\begin{array}{c}232014 \\
.97\end{array}$ & 1 & $\begin{array}{c}0.00 \\
717\end{array}$ & 1 & 4 & 1 \\
\hline 3 & $\begin{array}{l}\text { Industri } \\
\text { Pengolahan } \\
\end{array}$ & - & - & 1.21 & 1 & - & - & $\begin{array}{r}0.00 \\
614 \\
\end{array}$ & 1 & 2 & 2 \\
\hline 4 & $\begin{array}{l}\text { Listrik, Gas, } \\
\& \text { Air Bersih }\end{array}$ & - & - & 1.12 & 1 & - & - & - & - & 1 & 3 \\
\hline 5 & Bangunan & - & - & 1.20 & 1 & - & - & $\begin{array}{l}0.01 \\
540 \\
\end{array}$ & 1 & 2 & 2 \\
\hline 6 & $\begin{array}{l}\text { Perdagangan, } \\
\text { Hotel \& } \\
\text { Restauran } \\
\end{array}$ & - & - & 1.09 & 1 & - & - & $\begin{array}{c}0.00 \\
491\end{array}$ & 1 & 2 & 2 \\
\hline 7 & $\begin{array}{l}\text { Pengangkutan } \\
\& \\
\text { Komunikasi }\end{array}$ & - & - & - & - & - & - & - & - & - & - \\
\hline 8 & $\begin{array}{l}\text { Keuangan, } \\
\text { Persewaaan } \\
\text { \& Jasa } \\
\text { Perusahaan }\end{array}$ & 1.09 & 1 & - & - & $\begin{array}{c}54832 . \\
95\end{array}$ & 1 & - & - & 2 & 2 \\
\hline 9 & Jasa-jasa & - & - & 1.52 & 1 & - & - & $\begin{array}{l}0.00 \\
922 \\
\end{array}$ & 1 & 2 & 2 \\
\hline
\end{tabular}
daerah, serta pemerintah dapat 
Analisis Potensi Ekonomi Kabupaten Banyuwangi (Ahmad Afan Ayubi)

melakukan pengembangan dikedua sektor tersebut.

\section{PENUTUP}

Berdasarkan hasil perhitungan tiga alat analisis yaitu analisis LQ, MRP, dan Shift-Share kemudian dirangking untuk menentukan sektor prioritas maka dapat disimpulkan bahwa sektor yang tergolong dalam kategori prioritas pertama adalah sektor pertanian dan sektor pertambangan dan penggalian. Sektor ekonomi yang masuk prioritas kedua (ke-2) adalah sektor industri pengolahan, sektor bangunan, sektor perdagangan, hotel \& restauran, sektor Keuangan, persewaaan \& jasa perusahaan dan sektor jasa-jasa.

\section{DAFTAR PUSTAKA}

Adi Sutrisno, 2012. Analisis Ketimpangan Pendapatan Dan Pengembangan Sektor Unggulan Di Kabupaten Dalam Kawasan

Barlingmascakeb Tahun 20072010, Economics Development Analysis Journal, Vol 1, No 1, Hal 43-49.

Bambang Prishardoyo, 2008, "Analisis Tingkat
Pertumbuhan Ekonomi Dan

Potensi Ekonomi Terhadap

Produk Domestik Regional Bruto (Pdrb) Kabupaten Pati Tahun 2000-2005". JEJAK: Jurnal Ekonomi dan Kebijakan. Vol 1, No 1, September 2008. Hal 1-8

Badan Pusat Statistik (2012). Kabupaten Banyuwangi Dalam Angka. Banyuwangi.

Badan Pusat Statistik, 2014. PDRB

Atas Dasar Harga Konstan Menurut Lapangan Usaha 2008-2012 (Juta Rupiah). Provinsi Jawa Timur.

Boediono. 1992. Teori Pertumbuhan Ekonomi. Yogyakarta: BPFE UGM.

Davit Irawan, 2010, “Analisis Perubahan Struktur Ekonomi Dan Identifikasi Sektor Unggulan Di Kabupaten Magetan Tahun 1997-2008”. Skripsi pada Universitas Sebelas Maret Surakarta.

Haryono Wahyudi, 2004, "Kota Gombong Sebagai Pusat Pertumbuhan Di Kabupaten Kebumen". Tesis pada Universitas Diponegoro. 
Analisis Potensi Ekonomi Kabupaten Banyuwangi (Ahmad Afan Ayubi)

Hilal Almulaibari, 2011, “Analisis

Potensi Pertumbuhan Ekonomi

Kota Tegal Tahun 2004-2008".

Skripsi pada Universitas

Diponegoro.

http://www.banyuwangikab.go.id/ber

ita/laporan_khusus/banyuwang

i-economic-outlook-2012-

sectoral-analysis.html (diakses

pada $\underline{30 / 05 / 2014)}$

http://www.banyuwangikab.go.id/ber

ita/laporan_khusus/banyuwang

i-economic-outlook-macro-

analysis.html (diakses pada

30/05/2014)

http://www.kabarbanyuwangi.info/de

klarasikan-banyuwangi-

sebagai-pusat-pertumbuhan-

ekonomi-baru.html (diakses

pada $\underline{30 / 05 / 2014)}$

Lincolyn Arsyad, (1999). Pengantar

Perencanaan

Dan

Pembangunan Ekonomi

Daerah, Edisi Pertama, BPFE UGM, Yogyakarta.

Mudrajat Kuncoro (2000). Ekonomi

Pembangunan: Teori, Masalah dan Kebijakan (1st ed.). UPP

AMP YKPN. Yogyakarta.

Nailatul H, Irwan N, Mochammad R, 2011, “Analisis Pengembangan
Potensi Ekonomi Lokal Untuk

Menguatkan Daya Saing

Daerah Di Kabupaten Gresik".

Jurnal Administrasi Publik

(JAP), Vol 1, No.1. Hal 188-

196

Nudiatulhuda Mangun, 2007,

"Analisis Potensi Ekonomi

Kabupaten Dan Kota Di

Propinsi Sulawesi Tengah".

Tesis pada Universitas

Diponegoro.

Nugraha Putra A, 2013, “Analisis

Potensi Ekonomi Kabupaten

Dan Kota Di Provinsi Daerah

Istimewa Yogyakarta”. Skripsi

pada Universitas Islam Negeri

Syarif Hidayatullah Jakarta.

Prasetyo Soepono (1993). Analisis

Shft-Share: Perkembangan dan

Penerapan. Jurnal Ekonomi dan

Bisnis Indonesia. Vol 1 Tahun VIII.

Retno Zulaechah, 2011, “Analisis

Pengembangan Kota Magelang

Sebagai Pusat Pertumbuhan

Kawasan Purwomanggung

Jawa Tengah". Skripsi pada

Universitas Diponegoro. 
Analisis Potensi Ekonomi Kabupaten Banyuwangi (Ahmad Afan Ayubi)

Tarigan, Robinson, "Ekonomi

Regional Teori \& Aplikasi”.

Jakarta: Bumi Aksara. 2005

Tarigan, Robinson. "Ekonomi

Regional, Teori dan Aplikasi (edisi revisi)". Jakarta: Bumi Aksara. 2007.

Todaro, Michael P. 2003. Pembangunan Ekonomi di

Dunia Ketiga, Edisi Ke Delapan. Erlangga, Jakarta. 